STUDIA I PRACE WYDZIAŁU NAUK EKONOMICZNYCH I ZARZĄDZANIA nr 41, t. 2

\title{
Dariusz Czakowski*
}

Kujawsko-Pomorska Szkoła Wyższa w Bydgoszczy

\section{RYNEK ROŚLIN OKOPOWYCH W POLSCE. POZIOM, DYNAMIKA I UWARUNKOWANIA ROZWOJU}

\begin{abstract}
Streszczenie
W artykule podjęto próbę identyfikacji dynamiki i kierunku rozwoju rynku roślin okopowych w Polsce poprzez określenie relacji zasobowo-efektywnościowych związanych z uprawą ziemniaków i buraków cukrowych. Przeprowadzone badania dotyczą lat 1994-2013. Na ich podstawie okazało się, że pomimo postępującego procesu koncentracji i specjalizacji produkcji na rynku roślin okopowych w Polsce, którego skutkiem była znacząca redukcja areału uprawnego oraz liczby plantatorów, efektywność produkcji w okresie poakcesyjnym spadała. Jedynie dzięki dopłatom przyznawanym do produkcji buraków cukrowych na tym rynku wystąpił nieznaczny wzrost wskaźnika. Potwierdza to fakt, że plantatorzy roślin okopowych funkcjonują w warunkach tzw. kieratu technologicznego.
\end{abstract}

Słowa kluczowe: rynek roślin okopowych, rynek cukru, rynek ziemniaka, integracja europejska

\section{Wprowadzenie}

Pomimo korzystnej jakości gleb oraz sprzyjających warunków klimatycznych dla wzrostu roślin okopowych w Polsce od początku lat 90. XX wieku odnotowuje się gwałtowny spadek ich zbiorów oraz areału upraw. Znacząco zmniejszyła się także liczba plantatorów. Cechą charakterystyczną roślin okopowych

* E-mail: d.czakowski@kpsw.edu.pl 
w porównaniu do innych upraw polowych jest wysoka kapitałochłonność oraz pracochłonność produkcji. Dodatkowo wymagają one sadzenia w dużych odstępach od siebie ze względu plon o dużej masie. Chociaż do upraw okopowych zalicza się wiele roślin (m.in. słonecznik bulwiasty, brukiew, marchew, cykorię, buraki pastewne, rzepę), najważniejsze znaczenie w strukturze zbiorów w Polsce mają ziemniaki i buraki cukrowe'1.

Jednym z najistotniejszych wydarzeń, które kształtowały sytuację na rynku roślin okopowych w Polsce w ostatnich latach, było wejście do Unii Europejskiej. Akcesja spowodowała przystąpienie producentów rolnych do jednolitego rynku europejskiego. Zmieniło to znacząco sytuację, w której się znajdowali, ponieważ zniknęły ograniczenia w handlu z krajami unijnymi. Ponadto w wyniku akcesji gospodarstwa rolne zaczęły podlegać wspólnej polityce rolnej, która jest szczególnie aktywna w przypadku rynku cukru.

Celem niniejszego opracowania jest identyfikacja dynamiki i kierunku rozwoju rynku roślin okopowych w Polsce poprzez pryzmat akcesji do UE. Zostanie to osiągnięte przy pomocy określenia relacji zasobowo-efektywnościowych oraz dynamiki cen na rynku ziemniaków i buraków cukrowych.

\section{Metodyka badań}

Badania obejmowały długi okres, tj. 20 lat, i prowadzono je z perspektywy dwóch podokresów. Pierwszy, przedakcesyjny, objął lata 1994-2003; drugi, poakcesyjny, zawarł się w latach 2004-2013. Pozwoliło to nadać rozważaniom charakter porównawczy. Wykorzystane w pracy dane źródłowe pochodziły z Instytutu Ekonomiki Rolnictwa i Gospodarki Żywnościowej oraz Głównego Urzędu Statystycznego. Dla osiągnięcia zamierzonego celu badawczego wykorzystano m.in. indeksy dynamiki (posłużyły do porównania rozpatrywanych zjawisk w czasie) oraz analizę korelacji liniowej Pearsona, która pozwoliła na określenie siły oraz kierunku związków pomiędzy wybranymi zmiennymi związanymi z uprawą ziemniaków i buraków cukrowych. Ponadto przy pomocy wybranych wskaźników zostały zbadane relacje efektywnościowe.

S. Stańko, Zmiany i projekcje rozwoju na podstawowych rynkach rolnych w Polsce, Wydawnictwo SGGW, Warszawa 2013, s. 97. 


\section{Dynamika cen na rynku roślin okopowych w latach 1994-2013}

Zniesienie barier handlowych pomiędzy Polską a krajami unijnymi doprowadziło do ujednolicania się poziomu cen pomiędzy krajowym a unijnym rynkiem produktów rolnych, a także zagwarantowało większą ich stabilizację.

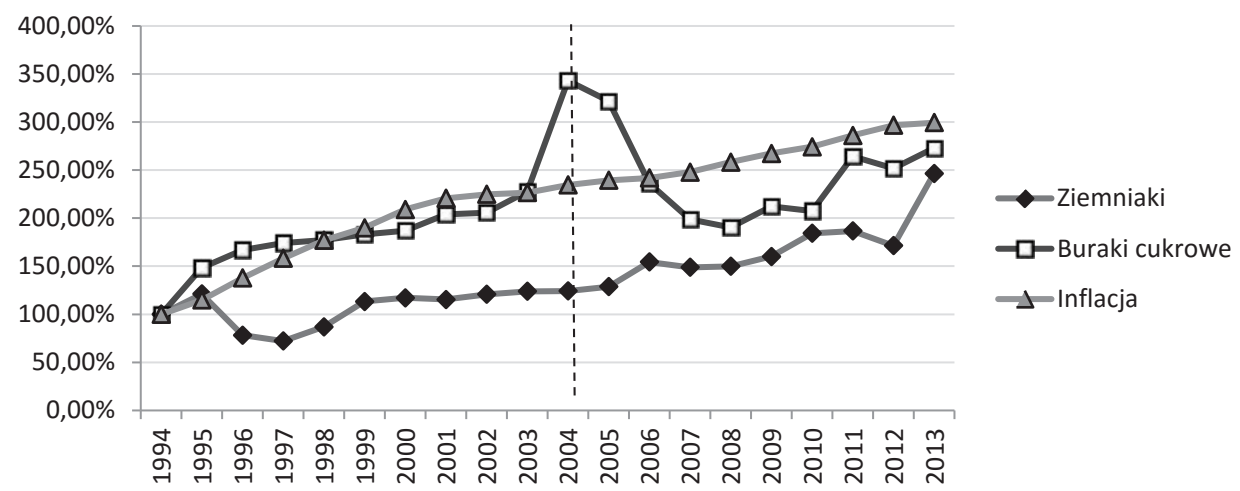

Rysunek 1. Skumulowana dynamika cen nominalnych skupu ziemniaków i buraków cukrowych oraz inflacji w Polsce w latach 1994-2013 (rok bazowy = 1994)

Źródło: Rynek ziemniaka. Stan i perspektywy, „Analizy Rynkowe” 1997-2014, nr 12-41; Rynek cukru. Stan i perspektywy, „Analizy Rynkowe” 1997-2014, nr 12-41 oraz dane GUS.

W ciągu całego badanego okresu skumulowana dynamika cen skupu ziemniaków kształtowała się na znacznie niższym poziomie niż zmiany inflacji (rysunek 1). W latach 1994-2013 inflacja wyniosła 299\%, natomiast ceny skupu ziemniaków wzrosły o $246 \%$. Należy jednak w tym miejscu zwrócić uwagę, że ten wynik był korzystniejszy od wieloletniej średniej i wynikał ze znaczącego wzrostu cen skupu ziemniaków w 2013 roku. Z drugiej strony warto wspomnieć, że ceny ziemniaków bardzo szybko wzrastały w latach 1991-1994, nieujętych w analizie, szybciej niż w przypadku zbóż. Przyśpieszyło to proces zastępowania ziemniaków jako paszy zwierzęcej przez rośliny zbożowe².

W latach 1994-2013 ceny skupu buraków cukrowych wzrosły o 273\%. Ponadto przez większość badanego okresu kształtowały się w sposób zbliżony do zmian inflacyjnych, zwłaszcza w okresie przedakcesyjnym. Ze względu na obowiązywanie licznych regulacji na rynku cukru ceny buraków cukrowych także były

2 J. Chotkowski, Perspektywy produkcji ziemniaków w Polsce w opiniach przedsiębiorstw nasiennych, „Biuletyn Instytutu Hodowli i Aklimatyzacji Roślin” 2008, nr 242, s. 153-154. 
uzależnione od instrumentów polityki interwencyjnej. Efekt tych działań był widoczny w 2004 roku, kiedy po akcesji do UE nastąpił gwałtowny wzrost cen buraków cukrowych w Polsce ze względu na konieczność dostosowania cen krajowych do obowiązujących we Wspólnocie cen minimalnych. Natomiast w wyniku zmiany regulacji rynku cukru w 2006 roku ceny skupu buraków uległy obniżeniu ${ }^{3}$.

\section{Podstawowe relacje zasobowe i efektywnościowe na rynku roślin okopowych przed akcesją i po akcesji do Unii Europejskiej}

Na rynku ziemniaka w Polsce zarysowuje się gwałtowny spadek średniorocznej powierzchni upraw (tabela 1). Ponadto znacząco spadła średnioroczna wielkość zbiorów ziemniaków przy stosunkowo niewielkim wzroście średniorocznego plonowania. Powyższe zmiany są efektem malejącego popytu. Najdotkliwiej skurczyło się zapotrzebowanie na ziemniaki z przeznaczaniem ich na pasze. Ze względu na niskie ceny na rynkach mięsnych oraz presję na optymalizację kosztów stały się one zbyt drogim sposobem na dostarczanie wartości odżywczej w stosunku do zbóż paszowych. Dodatkowo zmniejszył się także popyt konsumencki. Warto zaznaczyć, że zadecydował o tym spadek spożycia ziemniaków nieprzetworzonych, którego wzrost spożycia przetworów nie był w stanie zrekompensować.

Tabela 1. Średnioroczna wielkość powierzchni uprawy, plonów oraz zbiorów ziemniaków i buraków cukrowych w Polsce w latach 1994-2003 i 2004-2013

\begin{tabular}{|l|c|c|c|c|c|c|}
\hline \multirow{2}{*}{ Wyszczególnienie } & \multicolumn{3}{|c|}{ Ziemniaki } & \multicolumn{3}{c|}{ Buraki cukrowe } \\
\cline { 2 - 7 } & $\begin{array}{c}\text { powierzchnia } \\
\text { uprawy } \\
\text { (tys. ha) }\end{array}$ & $\begin{array}{c}\text { plony } \\
\text { (t/ha) }\end{array}$ & $\begin{array}{c}\text { zbiory } \\
\text { (mln ton) }\end{array}$ & $\begin{array}{c}\text { powierzchnia } \\
\text { uprawy } \\
\text { (tys. ha) }\end{array}$ & $\begin{array}{c}\text { plony } \\
\text { (t/ha) }\end{array}$ & $\begin{array}{c}\text { zbiory } \\
\text { (mln } \\
\text { ton) }\end{array}$ \\
\hline (1) 1994-2003 & 1244 & 17,5 & 21,47 & 367 & 35,3 & 13,61 \\
\hline (2) 2004-2013 & 506 & 20 & 9,95 & 223 & 51,6 & 11,35 \\
\hline Zmiana (2)/(1) & $-59 \%$ & $+15 \%$ & $-54 \%$ & $-39 \%$ & $46 \%$ & $-17 \%$ \\
\hline
\end{tabular}

Źródło: Rynek ziemniaka...; Rynek cukru...

K. Hryszko, P. Szajner, Sytuacja na światowym rynku cukru i jej wpływ na możliwości uprawy buraków cukrowych $w$ Polsce. Program Wieloletni 2011-2014, IERiGŻ PIB, Warszawa 2013, s. 84. 
Skala upraw buraków cukrowych w badanym okresie była determinowana poprzez wiele regulacji i instrumentów na rynku cukru, do których zalicza się m.in. kwoty produkcyjne, cła, wsparcie dochodów plantatorów. Szczególnie istotna była reforma z sezonu 2006/2007, wskutek której liczba cukrowni w Polsce zmniejszyła się z 78 do 18, a także wprowadzono limity produkcyjne. W związku z powyższym rynek cukru w Polsce ma strukturę klasycznego oligopolu 4 . Ponadto pomiędzy 1994 a 2013 rokiem liczba plantatorów buraków cukrowych zmalała o $87 \%$ - z 273 tys. do 36 tys. Z jednej strony spowodowało to spadek powierzchni upraw, ale z drugiej wpłynęło pozytywnie na wielkość uzyskiwanych plonów z hektara, ponieważ na rynku zostały większe obszarowo i efektywniejsze produkcyjnie gospodarstwa. Średnioroczne zbiory buraków cukrowych w latach 2004-2013 były o 17\% niższe niż w okresie 1994-2013. Wskazuje to, że wzrost plonów nie rekompensował ograniczenia produkcji w rezultacie mniejszej powierzchni upraw.

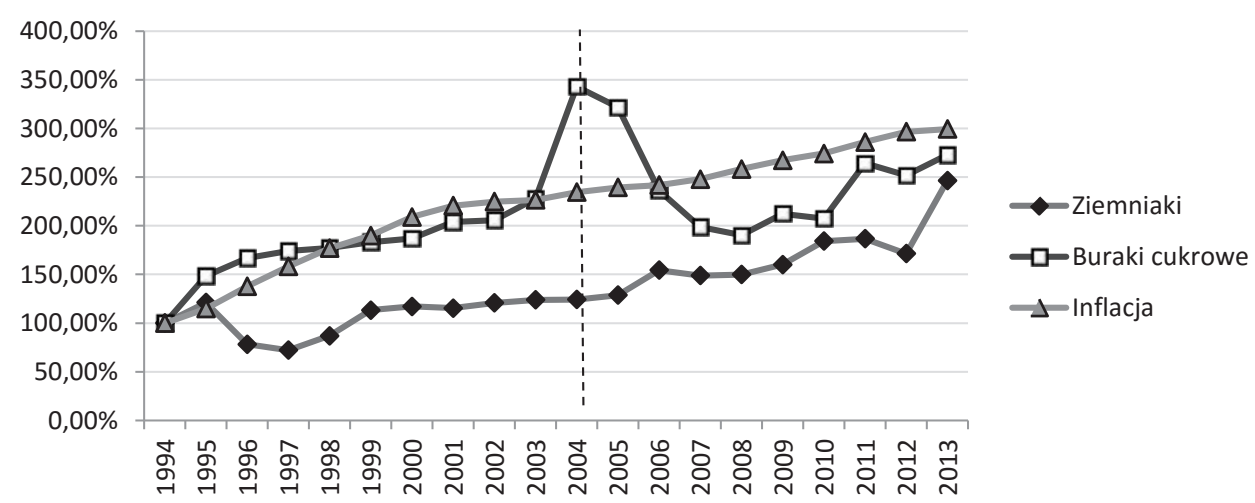

Rysunek 2. Średnioroczna wartość produkcji, kosztów, dopłat i dochodów z uprawy ziemniaków oraz buraków cukrowych w latach 1994-2003 i 2004-2013 (w przeliczeniu na 1 ha upraw, w zł)

Źródło: A. Skarżyńska, J. Sadowska, Koszty jednostkowe i dochodowość produkcji rolniczej w gospodarstwach indywidualnych w 1997 roku, IERiGŻ, Warszawa 1998; Produkcja, koszty i dochody wybranych produktów rolniczych w latach 2006-2007, red. I. Ziętek, IERiGŻ, Warszawa 2008; Produkcja, koszty i dochody wybranych produktów rolniczych w latach 2008-2009, red. M. Cholewa, IERiGŻ, Warszawa 2010; Produkcja, koszty i dochody wybranych produktów rolniczych w latach 2011-2012, red. I. Augustyńska-Grzymek, IERiGŻ, Warszawa 2013.

4 P. Szajner, Wplyw sytuacji na rynku na krajowy rynek produktów rolno-żywnościowych, w: Monitoring rynków rolno-spożywczych $w$ warunkach zmieniającej się sytuacji ekonomicznej. Synteza wyników z badań, red. P. Szajner, IERiGŻ PIB, Warszawa 2014, s. 20-21. 
Z zaprezentowanych na rysunku 2 danych wynika, że pomimo istotnego wzrostu wartości produkcji ziemniaków dochód z ich uprawy wzrósł nieznacznie ze względu na istotny wzrost kosztów. Dynamika średniorocznych dochodów pomiędzy badanymi okresami wyniosła 40\%, podczas gdy wartość produkcji wzrosła o $119 \%$, a koszty o 218\%. Natomiast w przypadku uprawy buraków cukrowych nastąpił znaczący wzrost średniorocznych dochodów (o 125\%), przede wszystkim dzięki występującym dopłatom do produkcji dla plantatorów. Średnioroczna wartość produkcji na tym rynku wzrosła o 59\%, a koszty o 89\%.

\section{Wybrane wskaźniki efektywnościowe na rynku roślin okopowych przed wstąpieniem i po wstąpieniu do Unii Europejskiej}

Obecnie na rynkach produktów rolnych obserwujemy działanie tzw. kieratu technologicznego. Mechanizm ten wymusza na rolnikach stałe zwiększanie wydajności pracy prowadzące do redukcji kosztów, która z kolei nie przekłada się na wzrost dochodów ze względu na malejące ceny surowców rolnych. Ponadto niemobilność ziemi oraz bryłowatość zainwestowanego w gospodarstwach rolnych majątku sprawiają, że rolnicy nie są w stanie przenieść czynników wytwórczych do alternatywnych zastosowań ${ }^{5}$.

Tabela 2. Kosztochłonność, produkcyjność i efektywność z uprawy ziemniaków oraz buraków cukrowych w latach 1994-2003 i 2004-2013

\begin{tabular}{|l|c|c|c|c|c|c|}
\hline & \multicolumn{3}{|c|}{ Ziemniaki } & \multicolumn{3}{c|}{ Buraki cukrowe } \\
\cline { 2 - 7 } & $\begin{array}{c}1994-2003 \\
(1)\end{array}$ & $\begin{array}{c}2004-2013 \\
(2)\end{array}$ & $\begin{array}{c}\text { zmiana } \\
(2) /(1) \\
(\%)\end{array}$ & $\begin{array}{c}1994-2003 \\
(3)\end{array}$ & $\begin{array}{c}2004-2013 \\
(4)\end{array}$ & $\begin{array}{c}\text { zmiana } \\
(4) /(3) \\
(\%)\end{array}$ \\
\hline $\begin{array}{l}\text { Kosztochłonność } \\
\text { (koszt/wartość produkcji) }\end{array}$ & 0,44 & 0,65 & 48 & 0,61 & 0,77 & 26 \\
\hline $\begin{array}{l}\text { Produkcyjność } \\
\text { (wartość produkcj//koszt) }\end{array}$ & 2,38 & 1,57 & -34 & 1,70 & 1,39 & -18 \\
\hline $\begin{array}{l}\text { Efektywność } \\
\text { (dochód/koszty ogółem) }\end{array}$ & 1,38 & 0,57 & -59 & 0,70 & 0,74 & 6 \\
\hline $\begin{array}{l}\text { Efektywność bez wliczania } \\
\text { dopłat dochodu }\end{array}$ & 1,38 & 0,57 & -59 & 0,70 & 0,39 & -44 \\
\hline
\end{tabular}

Źródło: A. Skarżyńska, J. Sadowska, Koszty jednostkowe...; Produkcja, koszty... w latach 2006-2007...; Produkcja, koszty... w latach 2008-2009; Produkcja, koszty... w latach 2011-2012..

\footnotetext{
A. Czyżewski, B. Czyżewski, Ziemia i jej renty w nowym paradygmacie rozwoju rolnictwa, w: Problemy rozwoju rolnictwa i gospodarki żywnościowej w pierwszej dekadzie członkostwa Polski w Unii Europejskiej, red. A. Czyżewski, B. Klepacki, PTE, Warszawa 2015, s. 32.
} 
Przedstawione w tabeli 2 wskaźniki dowodzą, że pomimo postępującego procesu koncentracji i specjalizacji produkcji na rynku roślin okopowych w Polsce, którego skutkiem była znacząca redukcja areału uprawnego oraz liczby plantatorów, spadła efektywność produkcji bez wliczania dopłat w okresie poakcesyjnym. W przypadku uprawy ziemniaków średnioroczny spadek wartości tego wskaźnika wyniósł $59 \%$, natomiast na rynku buraków cukrowych ten sam wskaźnik zmalał o 44\%, jednak wliczenie dopłat do dochodów plantatorów buraków cukrowych spowodowało średnioroczny wskaźnik efektywności o 6\%. Ponadto przy obydwu uprawach zanotowano wzrost wskaźnika kosztochłonności oraz spadek wskaźnika produkcyjności, co potwierdziło niekorzystne przeobrażenia na tym rynku.

\section{Podstawowe współzależności na rynku roślin okopowych w latach 1994-2013}

Wśród wielu interesujących związków przedstawionych w tabeli 3 warto zwrócić szczególną uwagę na główne determinanty wielkości zbiorów. Zarówno w przypadku ziemniaków, jak i buraków cukrowych była to powierzchnia uprawy. Z kolei zależność łącząca plony z wielkością zbiorów na obydwu rynkach była nieistotna statystycznie we wszystkich okresach. W przypadku ziemniaków trzykrotnie wystąpiła silna ujemna korelacja pomiędzy zbiorami a kosztami produkcji. Na rynku buraków cukrowych związek pomiędzy tymi zmiennymi był także za każdym razem ujemny, ale istotnie statystyczny tylko w przypadku analizowania całego okresu. Ponadto warto dodać, że ceny nie determinowały wielkości zbiorów na rynku buraków cukrowych, a w przypadku ziemniaków związek ten był dodatkowo silnie ujemny. Zatem można wysnuć wniosek, że na wielkość zbiorów na obydwu rynkach najsilniej wpływała powierzchnia upraw oraz poziom kosztów. 
Tabela 3. Wartości współczynników korelacji liniowej Pearsona odnoszących się do wybranych zmiennych związanych z uprawą ziemniaków i buraków cukrowych w Polsce w latach 1994-2013

\begin{tabular}{|l|l|c|c|c|}
\hline \multicolumn{1}{|c|}{ Zmienna 1 } & \multicolumn{1}{|c|}{ Zmienna 2 } & $1994-2003$ & $2003-2014$ & $1994-2013$ \\
\hline \multirow{5}{*}{ Zbiory ziemniaków } & Zbiory buraków cukrowych & 0,55 & 0,39 & 0,70 \\
\cline { 2 - 5 } & $\begin{array}{l}\text { Powierzchnia uprawy } \\
\text { ziemniaków }\end{array}$ & 0,78 & 0,83 & 0,95 \\
\cline { 2 - 5 } & Plony ziemniaków & 0,17 & $-0,15$ & $-0,40$ \\
\cline { 2 - 5 } & $\begin{array}{l}\text { Wartość produkcji } \\
\text { ziemniaków }\end{array}$ & $-0,45$ & $-0,47$ & $-0,80$ \\
\cline { 2 - 5 } & Cena ziemniaków & $-0,53$ & $-0,79$ & $-0,82$ \\
\cline { 2 - 5 } & Koszty uprawy ziemniaków & $-0,74$ & $-0,69$ & $-0,90$ \\
\hline \multirow{3}{*}{$\begin{array}{l}\text { Zbiory buraków } \\
\text { cukrowych }\end{array}$} & $\begin{array}{l}\text { Powierzchnia uprawy } \\
\text { buraków cukrowych }\end{array}$ & 0,73 & 0,58 & 0,78 \\
\cline { 2 - 5 } & Plony buraków cukrowych & 0,27 & 0,07 & $-0,33$ \\
\cline { 2 - 5 } & Cena buraków cukrowych & $-0,10$ & 0,58 & $-0,25$ \\
\cline { 2 - 5 } & $\begin{array}{l}\text { Wartość produkcji buraków } \\
\text { cukrowych }\end{array}$ & $-0,09$ & 0,66 & $-0,26$ \\
\cline { 2 - 5 } & $\begin{array}{l}\text { Koszty uprawy buraków } \\
\text { cukrowych }\end{array}$ & $-0,33$ & $-0,20$ & $-0,60$ \\
\hline $\begin{array}{l}\text { Powierzchnia uprawy } \\
\text { ziemniaków }\end{array}$ & $\begin{array}{l}\text { Powierzchnia uprawy } \\
\text { buraków cukrowych }\end{array}$ & 0,79 & 0,83 & 0,92 \\
\hline Plony ziemniaków & Plony buraków cukrowych & 0,20 & 0,81 & 0,68 \\
\hline Cena ziemniaków & Cena buraków cukrowych & 0,35 & $-0,18$ & 0,47 \\
\hline $\begin{array}{l}\text { Wartość produkcji } \\
\text { ziemniaków }\end{array}$ & $\begin{array}{l}\text { Wartość produkcji buraków } \\
\text { cukrowych }\end{array}$ & 0,95 & $-0,18$ & 0,61 \\
\hline $\begin{array}{l}\text { Koszty uprawy } \\
\text { ziemniaków }\end{array}$ & $\begin{array}{l}\text { Koszty uprawy buraków } \\
\text { cukrowych }\end{array}$ & 0,99 & 0,74 & 0,93 \\
\hline $\begin{array}{l}\text { Wartość produkcji } \\
\text { ziemniaków }\end{array}$ & Cena ziemniaków & 0,58 & 0,51 & 0,81 \\
\hline $\begin{array}{l}\text { Wartość produkcji } \\
\text { buraków cukrowych }\end{array}$ & Cena buraków cukrowych & 0,95 & 0,84 & 0,93 \\
\hline
\end{tabular}

Obliczenia wykonano z wykorzystaniem programu STATISTICA ver. 12, poziom istotności: $\mathrm{p}=0,05$.

Źródło: Rynek ziemniaka...; Rynek cukru... oraz dane GUS.

Współzależności pomiędzy badanymi zmiennymi na obydwu rynkach przebiegały bardzo podobnie. Ponadto wszystkie zmienne opisujące rynek ziemniaków były silnie dodatnio skorelowane $\mathrm{z}$ tymi samymi zmiennymi dotyczącymi rynku buraków cukrowych w długim okresie. Warto jeszcze wspomnieć, że na obydwu rynkach wartość produkcji była silnie determinowana poprzez kształtowanie się cen. 


\section{Podsumowanie}

Reasumując wyniki badań, można stwierdzić, że na rynku roślin okopowych w Polsce w badanym okresie przebiegały systematyczne procesy koncentracji i specjalizacji produkcji. Odbywało się to kosztem znacznego zmniejszenia powierzchni upraw oraz liczby plantatorów. W przypadku uprawy buraków cukrowych proces ten uległ dynamizacji w związku z wprowadzeniem nowych regulacji na rynku cukru, które zbiegły się w czasie z pierwszymi latami członkowstwa Polski w UE. Wśród pozostałych uwarunkowań rozwoju rynku roślin okopowych w Polsce należy zwrócić szczególną uwagę na:

Kształtowanie się skumulowanej dynamiki cen skupu ziemniaków znacznie poniżej skumulowanej dynamiki inflacji. Procesowi temu towarzyszył dodatkowo spadek popytu konsumpcyjnego na ziemniaki, jak również gwałtowny spadek zużycia ziemniaków z przeznaczeniem na spasanie w związku z relatywnie niższym kosztem karmienia zwierząt hodowlanych paszami zbożowymi.

Ceny buraków cukrowych były w dużej mierze zależnie od regulowanych ustawo cen skupu. W pierwszych dwóch latach członkowstwa we Wspólnocie na rynku buraków cukrowych wystąpiły znaczące podwyżki związane z dostosowaniem minimalnych cen skupu do tych obowiązujących w UE. Natomiast reforma rynku cukru z sezonu 2006/2007 spowodowała obniżenie cen buraków cukrowych. Obecne reformy zmierzają do liberalizacji europejskiego rynku cukru poprzez zniesienie kwot produkcyjnych, co może doprowadzić w początkowym okresie do destabilizacji rynku i dużych wahań cenowych.

Efektywność produkcji, liczona jako stosunek dochodu z prowadzonej działalności bez wliczania dopłat do kosztów ogółem zmniejszyła się wśród gospodarstw uprawiających zarówno ziemniaki, jak i buraki cukrowe w okresie po akcesji do UE (2004-2013), z tym że plantatorzy buraków cukrowych otrzymywali od 2004 roku dopłaty do produkcji, które po wliczeniu do dochodu spowodowały nieznaczny wzrost wartości skorygowanego wskaźnika efektywności. Powyższe relacje efektywnościowe znalazły odbicie w wielkości zbiorów, które średniorocznie pomiędzy okresem przed- i poakcesyjnym gwałtowniej spadły na rynku ziemniaka (o 54\%). Na rynku buraków cukrowych niniejsza wartość pomniejszyła się o $17 \%$.

Wielkość zbiorów na obydwu rynkach najsilniej była determinowana poprzez powierzchnię upraw oraz poziom kosztów. Ponadto wszystkie badane w analizie korelacji zmienne na rynku ziemniaków (wielkość zbiorów, powierzchnia upraw, plony, ceny, wartość produkcji oraz koszty) były dodatnio i istotnie skorelowane $\mathrm{z}$ analogicznymi zmiennymi na rynku buraków cukrowych. 


\section{Literatura}

Chotkowski J., Perspektywy produkcji ziemniaków w Polsce w opiniach przedsiębiorstw nasiennych, „Biuletyn Instytutu Hodowli i Aklimatyzacji Roślin” 2008, nr 242.

Czyżewski A., Czyżewski B., Ziemia i jej renty w nowym paradygmacie rozwoju rolnictwa, w: Problemy rozwoju rolnictwa i gospodarki żywnościowej w pierwszej dekadzie członkostwa Polski w Unii Europejskiej, red. A. Czyżewski, B. Klepacki, PTE, Warszawa 2015.

GUS, www.stat.gov.pl/gus

Hryszko K., Szajner P., Sytuacja na światowym rynku cukru i jej wptyw na możliwości uprawy buraków cukrowych w Polsce, IERiGŻ PIB, Warszawa 2013.

Klepacki B., Szymańska E., Zmiany w wykorzystaniu ziemniaków na pasze w Polsce, „Biuletyn Instytutu Hodowli i Aklimatyzacji Roślin” 2008, nr 242.

Krzemiński M., Zmiany w handlu zagranicznym w: Rynek ziemniaka i ewolucja jego funkcjonowania oraz wplyw na proces transmisji cen, red. J. Seremak-Bulge, IERiGŻ PIB, Warszawa 2006.

Produkcja, koszty i dochody wybranych produktów rolniczych w latach 2002-2005, red.

A. Skarżyńska, IERiGŻ, Warszawa 2006.

Produkcja, koszty $i$ dochody wybranych produktów rolniczych w latach 2006-2007, red. I. Ziętek, IERiGŻ, Warszawa 2008.

Produkcja, koszty i dochody wybranych produktów rolniczych w latach 2008-2009, red. M. Cholewa, IERiGŻ, Warszawa 2010.

Produkcja, koszty $i$ dochody wybranych produktów rolniczych w latach 2011-2012, red.

I. Augustyńska-Grzymek, IERiGŻ, Warszawa 2013.

Rynek cukru. Stan i perspektywy, „Analizy Rynkowe” 1997-2014, nr 12-41.

Rynek ziemniaka. Stan i perspektywy, „Analizy Rynkowe” 1997-2014, nr 12-41.

Skarżyńska A., Sadowska J. Koszty jednostkowe i dochodowość produkcji rolniczej w gospodarstwach indywidualnych $w 1997$ roku, IERiGŻ, Warszawa 1998.

Stańko S., Zmiany i projekcje rozwoju na podstawowych rynkach rolnych $w$ Polsce, Wydawnictwo SGGW, Warszawa 2013.

Szajner P., Wpływ sytuacji na rynku na krajowy rynek produktów rolno-żywnościowych, w: Monitoring rynków rolno-spożywczych $w$ warunkach zmieniajacej się sytuacji ekonomicznej. Synteza wyników z badań, red. P. Szajner, IERiGŻ PIB, Warszawa 2014. 


\title{
ROOT PLANTS MARKET IN POLAND. LEVEL, DYNAMICS AND CONDITIONS OF DEVELOPMENT
}

\begin{abstract}
The article attempts to identify the dynamics and direction of market development root crops in Poland through to determine the relationship resource, improving the efficiency associated with the cultivation of potatoes and sugar beet. The studies concluded in the period 1994 to 2013. On this basis, it turned out that despite the ongoing process of concentration and specialization of production on the market in Poland, root crops, resulting in a significant reduction in cultivated acreage and number of growers, production efficiency significantly decreased post-accession period. Only thanks to the subsidies granted to the production of sugar beet, in this market there was a slight increase in this indicator. This confirms therefore that the root crop growers operating under the so-called "technological treadmill".
\end{abstract}

Translated by Dariusz Czakowski

Keywords: agricultural commodity prices, market root crops, sugar market, the market for potato, European integration

JEL codes: G01, D24, F29 
